УДК 351.77

DOI https://doi.org/10.32838/TNU-2663-6468/2020.3/22

\title{
Леган I.M.
}

Державний університет «Житомирська політехніка»

Крикун О.Д.

Міжрегіональна академія управління персоналом

\section{НАПРЯМИ ВДОСКОНАЛЕННЯ ДЕРЖАВНОГО РЕГУЛЮВАННЯ РИНКУ ПРИВАТНОЇ МЕДИЦИНИ}

У статті проведено комплексне дослідження сутності та значення ринку приватної медицини. Висвітлено суттєві особливості системи охорони здоров'я як вкрай важливого сектора соціально-економічного життя населення держави. Охарактеризовано ряд факторів, щзо істотно впливають на функціонування ринку приватної медицини в Украйні. Доведено, щуо оскільки приватна система медичних закладів бере участь у реалізації не тільки приватних, а й сочіально-публічних інтересів, то виникає необхідність державного регулювання та контролю реалізації цчих інтересів. Проведено огляд основних иілей, шляхів та напрямів державного регулювання ринку приватної медицини України. Проаналізовано, щзо перспективи розвитку ринку приватної медицини залежать не стільки від макроекономічних і сочіальних параметрів, скільки від державної політики в області реформування медичної галузі. Доведено участь держави у розвитку ринку приватної медицини шляхом видачі лічензій на здійснення господарської діяльності в медичній практиці як фізичним особам-підприсмиям, так і юридичним особам. Охарактеризовано можливість участі у системі страхування медичних закладів недержавної форми власності. Окреслено, щзо необхідних кроків держави щуодо розвитку державно-приватного партнерства у сфері охорони здоров'я недостатньо. Суттєвими причинами иьього є неготовність держави до такого виду співробітництва, відсутність чіткого розмежування повноважень між органами державної влади, неналежне їх кадрове забезпечення, відсутність ефективного механізму надання державної підтримки у сфері державно-приватного підприємництва. Підтверджено, шзо наявність розвинутого ринку приватної медицини полегшить навантаження на державну систему охорони здоров'я шляхом обслуговування частини громадян, спроможних самостійно сплачувати за лікування. Виявлено, щзо зміни у стратегї̈ державного управління приватними медичними закладами є необхідною передумовою розвитку кардинально нового розвиненого та потенційно здорового суспільства.

Ключові слова: приватна медичина, медичні заклади, медичні послуги, приватні медичні заклади, система охорони здоров'я, ринок приватної медицини, ринок приватних медичних послуг.

Постановка проблеми. Перспективи розвитку ринку приватної медицини залежать не тільки від макроекономічних і соціальних параметрів, а також і від політики, яку проводить держава в області реформування медичної галузі. Держава підтримує розвиток ринку приватної медицини: щорічно МО3 України видає близько 2000 ліцензій на здійснення господарської діяльності в медичній практиці фізичним особам-підприємцям і юридичним особам. Крім того, один із законопроектів i3 питань запровадження загальнообов'язкового державного соціального медичного страхування, внесений до парламенту України, передбачає можливість участі в системі страхування медичних установ недержавної форми власності. Але кроків, яких вживає держава щодо розвитку державноприватного партнерства у сфері охорони здоров'я, недостатньо. Причиною цього є неготовність держави до такого співробітництва, недосконалість системи керування розвитком державно-приватного партнерства, відсутність чіткого розмежування повноважень між органами державної влади, неналежне їх кадрове забезпечення, відсутність ефективного механізму надання державної підтримки у сфері державно-приватного підприємництва [1]. Наявність розвинутого ринку приватної медицини полегшить навантаження на державну систему охорони здоров'я, оскільки він обслуговує частину громадян, спроможних самостійно сплачувати за лікування. 
Аналіз останніх досліджень і публікацій. Суттєвий внесок у дослідження проблем здоров'я населення як фактора економічного зростання було зроблено такими вітчизняними вченими: В. Геєць, О. Грішновою, І. Курило, Н. Левчук, Е. Лібановою, О. Макаровою, І. Манцуровим, В. Онікієнко, О. Осауленко, С. Пирожковим, Н. Рингач, А. Сердюк, В. Стешенко, В.Т аралло, А. Філіпенко та іншими. Водночас досі недостатньо дослідженими залишаються питання державного регулювання ринку приватної медицини в Україні та дієвих напрямів його удосконалення.

Постановка завдання. Метою статті $є$ комплексне дослідження напрямів удосконалення державного регулювання ринку приватної медицини в Україні.

Виклад основного матеріалу дослідження. Сьогодні стан закладів приватної медицини в загальній системі охорони здоров'я України характеризується незначною увагою держави до розвитку ринку приватної медицини, $\mathrm{i}$, як наслідок, відказом (з іiі боку) від активної участі в організації державно-приватного партнерства. Водночас медичні працівники ринку приватної медицини, так само як державні медичні працівники, сприяють досягненню спільної мети відновленню й збереженню найбільшої цінності населення, його здоров'я. Саме тому в інтересах держави - зміна ii відношення до ринку приватної медицини, проведення політики рівності підходів як до медичних працівників приватної медицини, так і їхніх пацієнтів.

Державне регулювання ринку приватної медицини має включати сукупність організаційно-правових норм та механізмів державних органів, що спрямовуватимуться на координацію діяльності, яка сприятиме забезпеченню заходів політичного, економічного, правового, соціального, медичного характеру. Розвиток ринку приватної медицини залежить від стану економіки, законодавчих ініціатив у галузі охорони здоров'я, розвитку державно-приватного партнерства, нормативноправових аспектів діяльності, пов'язаних у тому числі з охороною приватної власності.

Першочерговим напрямом удосконалення державного регулювання ринку приватної медицини є включення до Указів Президента України, Постанов уряду України, Законів України, які стосуються реформи охорони здоров'я, декларування повної рівноправності приватної і державної медицини в усіх сферах діяльності. Із цією метою на всіх рівнях державних органів управління охороною здоров'я доцільним $є$ створення під- розділів із розвитку ринку приватної медицини. Окрім того, на законодавчому рівні мають бути чітко зумовлені обмеження для суб'єктів приватної медичної діяльності з надання медичних послуг та медичної допомоги певного виду. Встановлення таких обмежень для суб'єктів приватної медичної діяльності зі здійснення окремих видів медичної допомоги та надання окремих медичних послуг є не тільки цілком обгрунтованим, а й необхідним заходом. Адже одна справа, коли приватні медичні установи концентруються в таких напрямках медицини, як стоматологія, офтальмологія, гінекологія, косметологія, пластична хірургія. І інша справа, коли приватний сектор охорони здоров'я допускається до лікування небезпечних захворювань, що вимагає особливого державного контролю. І хоча в науковій літературі висловлюється думка, що таке обмеження необгрунтоване й стримує розвиток підприємницької ініціативи, в тому числі у сфері приватної медицини, однак характерна для сфери медичних послуг соціальна $\mathrm{i}$, деякою мірою, політична спрямованість не завжди сприймає комерційний підхід у питанні визначення виконавця медичної допомоги та медичних послуг.

Той факт, що у відношенні приватних медичних установ відсутні спеціальні законодавчі заборони і обмеження на здійснення ними окремих видів діяльності, вказує на те, що в Україні створені рівні можливості для функціонування медичних установ різних форм власності. Це, у свою чергу, свідчить про недосконалість і прорахунок у правовому регулюванні ринку приватної медицини. 3 огляду на це обов'язковим є створення на законодавчому рівні такого ставлення до приватної медицини, за якого вона сприймалася б не як звичайний різновид підприємницької діяльності, а як необхідна і невід'ємна частина системи охорони здоров'я, що виконує важливу соціальну функцію, яка сприятиме введенню приватної медицини в жорсткі правові межі.

3 огляду на це слід обмежити діяльність приватних медичних закладів за допомогою прямого перерахування в законодавчих документах 3 охорони здоров'я видів медичної допомоги та медичних послуг, надання яких $є$ забороненим для суб'єктів приватної медичної діяльності, включивши до переліку цих послуг лікування небезпечних захворювань й вчинення медичних маніпуляцій, які потребують особливого державного контролю, а також створення на всіх рівнях державних органів управління охороною здоров'я підрозділів з розвитку ринку приватної медицини. 
Серед основних проблем, які стримують розвиток ринку приватної медицини в Україні, $є$ відсутність необхідних приміщень. Адже більшість приватних медичних центрів розміщено в житлових будинках, у яких існує безліч обмежень щодо санітарних норм. Тому серед напрямів державного регулювання необхідним $є$ стимулювання розробки та впровадження регіональних програм із будівництва спеціальних приміщень під медичну діяльність. При цьому цільові договори оренди приміщень для здійснення приватної медичної діяльності повинні укладатися строком не менше, ніж на 10 років або безстроково.

Заслуговує на удосконалення та підтримку 3 боку держави й система приватного страхування здоров'я. Встановлено, що на сучасному етапі вона значно ускладнює державну підтримку населення, яке не здатне оплатити вартість лікування, адже не забезпечує загальнодоступний мінімум надання медичної допомоги та необхідний рівень централізації фінансових засобів, що, у свою чергу, перешкоджає державі здійснювати прямий контроль над витратами галузі й призводить до підвищення вартості медичних послуг. 3 огляду на це 3 метою досягнення оптимального розподілу ресурсів у сфері охорони здоров'я необхідно на загальнонаціональному рівні під контролем держави здійснити централізацію страхових внесків (гарантія від інфляції попиту) та контроль над формуванням витрат у медицині (гарантія від інфляції пропозиції).

Відкриття страховими компаніями власних клінік $€$ ще однією тенденцією для розвитку ринку приватної медицини та вдосконалення його державного регулювання. Зокрема, оскільки страхова компанія виступає посередником між лікарем i пацієнтом, вона зацікавлена у скороченні термінів лікування та виплат за лікарняними з метою зниження обсягу необгрунтованих страхових виплат i забезпечення якнайшвидшого одужання пацієнта. У зв’язку з низькою якістю медичних послуг i застосуванням щодо пацієнта значних, а іноді i необгрунтованих лікувально-діагностичних втручань, відносини між наявними медичними закладами і страховими компаніями загострюються. Одним із варіантів вирішення цієї проблеми $\epsilon$ створення медичного закладу, повний контроль за яким буде здійснювати страхова компанія. Це дасть можливість регулювати ціни і якість наданих послуг [3]. Яскравим прикладом можна вважати медичну мережу «Добробут».

У сучасних умовах держава покладає на себе функцію контролю якості та безпеки діяльності закладів охорони здоров'я і приватних медичних організацій. Між тим сфера технічного регулювання повинна бути обмежена тільки завданнями захисту життя і здоров'я населення. У зв'язку із цим державне регулювання має застосовуватися лише в тих випадках, коли воно не може здійснюватися самою приватною медичною організацією під тиском ринку або суттєво підвищує безпеку пацієнтів і працівників. За таких умов технічне державне регулювання може здійснюватися через м'які механізми, такі як обов'язкове декларування та добровільна державна сертифікація. Обов'язкове декларування передбачає обов'язок підприємця повідомити державному органу влади інформацію щодо безпеки наданих ним послуг. Декларування заміняє собою контроль, який проводиться інспекторами 3 виїздом до приватного медичного закладу. Ефективність декларування підтверджується практикою у сфері оподаткування. У свою чергу, добровільна державна сертифікація може здійснюватися в тих випадках, коли виникають побоювання, що громадяни не зможуть здійснити самостійно правильний вибір постачальника послуг, що пов'язано 3 їхньою високою технологічною складністю. У цьому випадку держава в добровільному порядку та за відповідну плату здійснює сертифікацію послуг, які надаються на ринку приватної медицини, що дозволяє закладам приватної медицини залучити споживачів, які довіряють державному органу сертифікації. Необхідність у добровільній державній сертифікації найбільш дієва на початковому етапі розвитку ринку, коли пропозиція приватних сертифікаційних послуг відсутня.

Наступним важливим напрямом удосконалення державного регулювання ринку приватної медицини, поряд із технічним регулюванням, $\epsilon$ цивільно-правове. Пріоритет повинен віддаватися диспозитивним правовим нормам, зокрема тим, які діють лише у випадках, не врегульованих цивільно-правовими договорами. У даний час цивільне законодавство тяжіє до встановлення імперативних норм, що регулюють діяльність охорони здоров'я, договір же встановлює лише ті особливості надання медичних послуг, які не врегульовані законодавством України, включаючи накази відповідних відомств. Розвиток громадянського законодавства в даній сфері має здійснюватися випереджальними темпами, 3 урахуванням досвіду розвинених країн світу. Відмова ж від реформи цивільного законодавства може призвести до затримки розвитку ринку приватної медицини. У цьому випадку можливі й нега- 
тивні соціальні наслідки, в тому числі збільшення тіньової медичної сфери.

Держава повинна здійснювати стимулювання приватних постачальників до обмеження їхньої участі в наданні так званих громадських послуг, тобто послуг, які за своєю природою не можуть бути надані окремим споживачам, а надаються всьому суспільству. Перелік таких послуг повинен бути максимально скорочений, виходячи зі світової практики, а послуги повинні, за можливості, надаватися приватними медичними організаціями, які отримали державне замовлення в результаті відкритого конкурсу. Ні за яких умов держава не повинна обмежувати діяльність приватних медичних закладів із надання альтернативних громадських послуг.

Слід зазначити, що приватні медичні організації також не повинні виконувати функції соціальної допомоги. Такий вид допомоги має покладатися на державу, яка може вводити спеціальні субсидії, що дозволяють громадянам придбати медичні послуги на вільному ринку. На конкурсній основі держава може укладати відповідні цивільно-правові договори із приватними медичними організаціями на пільгове обслуговування тих чи інших соціально не захищених верств населення у випадках, коли пряме субсидування таких пацієнтів призводить до неефективного використання бюджетних коштів.

Підвищенню ролі ринку приватної медицини в розбудові загальної системи охорони здоров'я України може сприяти об'єднання фінансових і матеріальних ресурсів держави й бізнесу. Складовими частинами державно-кооперативного механізму фінансової сталості охорони здоров'я $\epsilon$ :

- соціально відповідальний бізнес;

- державно-приватне партнерство;

- соціальний діалог.

Так, соціальна відповідальність бізнесу передбачає добровільну позитивну реакцію підприємців на вирішення соціальних проблем суспільства. Такий підхід зумовлює не тільки виконання роботодавцем наявних нормативних правил і законів, але і бажання сприяти поліпшенню соціальноекономічної ситуації понад вимог, визначених у законодавчих актах. У зв'язку з тим, що соціальна політику України майже не враховує весь спектр корпоративної підтримки медицини, домінуюча роль у ній належить саме державі. Однак держава не в змозі повною мірою забезпечити розвиток інфраструктури медичного обслуговування населення, що вимагає зміни статусу медичних закладів із бюджетного на автономний, що зна- чно розширить участь недержавних організацій у ринкових відносинах та забезпечить детінізацію фінансування охорони здоров'я.

Саме тому окремим питанням розвитку та регулювання ринку приватної медицини з боку держави $\epsilon$ необхідність у детінізації та легалізації цього сектору, оскільки частина коштів потрапляє в медичну галузь прямо від пацієнтів, ці гроші залишаються в тіні, 3 них не виплачуються податки, що підтверджується висновками міжнародних експертів [5]. Легалізація може бути ефективною в разі створення певного лікарняного фонду, до якого пацієнти матимуть змогу перераховувати «вдячність» разом із персоналізацією даних медичного співробітника. А далі кожен медик отримуватиме частину грошей із цього перерахування, а також сплачуватиме відповідні податки.

3 огляду на вищезазначене одним із найважливіших питань, яке сьогодні потребує державного регулювання, є норми податкового кодексу, які різними способами створюють певні перепони, наприклад, будь-яке підприємство чи бізнес в Україні не може прямо сплатити кошти медичному закладу за послуги, які отримують його співробітники. Іншим питанням є податок на додану вартість, адже сьогодні норма Податкового кодексу України має суперечливі значення щодо податку на додану вартість із приводу медичної послуги. Наприклад, податок на додану вартість має бути нарахований на такий вид медичної допомоги, як профілактичний огляд, що суперечить профілактичному напрямку медицини взагалі [4].

Для вдосконалення податкової системи України повинні враховуватися також:

1) принципові завдання розвитку ринку приватної медицини, яка повинна мати диференційний характер, а також враховувати особливості міжнародного ринку медичних послуг та забезпечувати для українських медичних закладів, як мінімум, рівні конкурентні умови під час діяльності на цьому ринку;

2) відмінності в рентабельності різних видів медичної діяльності; не повинні створюватись необгрунтовані конкурентні переваги;

3) необхідність забезпечення умов для оптимального відтворення об'єктів інфраструктури охорони здоров'я з урахуванням їхньої високої фондоємності та амортизації;

4) стимулювання застосування ресурсозберігаючої і екологічно орієнтованої медичної техніки й технологій.

Висновки. Для розвитку співпраці суб'єктів ринку приватної медицини 3 державою слід при- 
вести також у відповідність нормативно-правову базу, що регламентує діяльність приватних медичних закладів та знайти рішення проблем, які пов’ язані з реалізацією норм Закону України «Про державно-приватне партнерство» у сфері охорони здоров'я. Зокрема, як доречно стверджують С. Підгайця та Т. Сіташ, «у межах державно-приватного партнерства доцільно ввести соціальні замовлення приватним медичним закладам і установам на ті діагностичні та лікувальні медичні послуги, які поки що не готові надавати державні та комунальні медичні заклади. Залучення бізнесу до виконання державних і місцевих програм соціально-економічного розвитку в межах державно-приватної взаємо- дії сприятиме задоволенню медичних потреб населення» [2]. 3 огляду на це необхідною є розробка дієвої системи сприяння розвитку ринку приватної медицини як соціально значущого сектору економіки, в основі якої має бути відповідний комплекс заходів щодо пільгового оподаткування, кредитування, оплати комунальних послуг, партнерського рівноправ'я державних і приватних закладів охорони здоров'я тощо. Суттєвим механізмом управління 3 підвищення ефективності охорони здоров'я може стати розвинення конкуренції за надання медичних послуг та допомоги за рахунок засобів бюджетного фінансування, приватного сектору та медичного страхування.

\section{Список літератури:}

1. Урсол Г.М. Приватний сектор системи охорони здоров'я - активний резерв підвищення доступності та якості надання медичної допомоги: досвід Кіровоградської області. Буковинський медичний вісник. 2014. Т. 18, № 4(72). С. 177-181.

2. Підгаєць С.В., Сіташ Т.Д. Проблеми та перспективи розвитку державно-приватного партнерства в системі охорони здоров’я. URL : http://dspace.tneu.edu.ua/bitstream/316497/9944/1/ 97.pdf.

3. Вовк С.М. Інституційна трансформація сучасних механізмів державного управління охороною здоров’я. Вісник Національного університету цүивільного захисту Украӥни: зб. наук. пр. 2017. Харків : Вид-во НУЦЗУ. № 2(70). С. 208-216.

4. Карлаш В.В. Державне регулювання реформуванням системи охорони здоров'я України. Інвестиції: практика та досвід. 2019. № 15. C. 121-124.

5. Karlash V.V. Problems of government regulation in the health of Ukraine. Public management. 2019. № 2(17). P. 78-84.

\section{Legan I.M., Krykun O.D. DIRECTIONS FOR IMPROVING STATE REGULATION OF THE PRIVATE MEDICINE MARKET}

The article conducts a comprehensive study of the nature and significance of the market of private medicine. The essential features of the health care system as an extremely important sector of the socio-economic life of the population of the state are highlighted. A number of factors that significantly affect the functioning of the market of private medicine in Ukraine are described. It is proved that since the private system of medical institutions participates in the realization of not only private but also social and public interests, there is a need for state regulation and control of the realization of these interests. The review of the main goals, ways and directions of state regulation of the market of private medicine of Ukraine is carried out. It is analyzed that the prospects for the development of the private medicine market depend not so much on macroeconomic and social parameters as on the state policy in the field of health care reform. The participation of the state in the development of the market of private medicine by issuing licenses for economic activity in medical practice to both natural persons-entrepreneurs and legal entities is proved. The possibility of participation in the insurance system of non-state medical institutions is characterized. It was emphasized that the necessary steps of the state to develop public-private partnership in the field of health care are not enough. The main reasons for this are the unwillingness of the state to this type of cooperation, the lack of clear division of powers between public authorities, their inadequate staffing, the lack of an effective mechanism for providing state support in the field of public-private entrepreneurship. It is confirmed that the presence of a developed market of private medicine will ease the burden on the state health care system by serving some citizens who are able to pay for treatment themselves. It was found that changes in the strategy of public administration of private medical institutions are a necessary prerequisite for the development of a radically new developed and potentially healthy society.

Key words: private medicine, medical institutions, medical services, private medical institutions, health care system, private medicine market, private medical services market. 